\title{
THE USE OF INDICATORS IN THE EVALUATION OF RETAIL PLANNING: EVIDENCES FROM ENGLAND
}

\author{
Pedro Porfírio Coutinho GUIMARÃES \\ Centre for Geographical Studies, Institute of Geography and Spatial Planning, \\ Universidade de Lisboa, Rua Branca Edmée Marques, 1600-216 Lisboa, Portugal \\ E-mail:pedroguimaraes@campus.ul.pt
}

Received 17 August 2015; accepted 26 November 2015

\begin{abstract}
Retail planning gained importance with the introduction of innovation in that sector, which challenged the vitality and viability of town centres. With this evolution and the arise of Town Centre First in England, the retail planning key documents started to incorporate indicators to help and standardize the monitoring of the health of town centres. This article aims to analyse the process of evaluation and verify the evolution of indicators suggested in the several public documents that constitute retail planning in England since 1993. It was based on the review of the main documents established in England since 1993. The research developed in this paper helps to update some information and is valuable for urban planners, practitioners and academics. In this paper we conclude that indicators are been used but without been framed in an evaluation framework and the variability of suggested indicators may have limited the analysis of the temporal evolution of town centres. In terms of research implications this paper helps to, in part, path the way for future research in this field.
\end{abstract}

Keywords: evaluation, retail planning, England, indicators, Planning Policy Guidance, Planning Policy Statement.

\section{Introduction}

Retail is a private activity through which goods and services are sold and, although not restricted to urban areas, it's in these areas that it reaches its maximum expression. The public regulation of retail has gained importance over the last decades in several Western European countries (as example see: Netherlands (Spierings 2006; Evers 2002); France (Colla 2003); Germany (Barth, Hartmann 2003); Sweden (Kärrholm 2012)). The changes in this sector caused a decrease in the vitality and viability of town centres (see Ravenscroft 2000; Schiller 1994; URBED 1994). Usually referred as retail planning, one may considered it as the regulation carried out on retail sector which reflect, directly or indirectly, the national development strategy of the sector (Guimarães 2016). In the English context, among many others, authors such as Guy $(2007,2002)$, Findlay and Sparks (2014) have worked on this subject. The regulation in this country has been characterized by the development of Planning Policy Guidance's and Statements. Associated with these documents is the provision of indicators to analyse the health of town centres (Communities and Local Government 2009, 2012; Department of the Environment 1996). The role of private associations has also been relevant in this process, of which one may enhance the Association of Town \& City Management (former Association of Town Centre Management) with the release of reports and Town Centre Health Check (Association of town centre management 2015). Recently, a study commissioned by this association and by Coca-Stefaniak (Coca-Stefaniak 2013) introduced a new set of indicators to measure town centre performance.

\section{Material and methods}

This article aims to analyse the process of evaluation and verify the evolution of indicators suggested in the several documents that constitute retail planning in England since 1993. This study was based on the analysis of the key documents that set the framework of retail planning of that country. In the following section we will discuss the process of evaluation. Subsequently, we will focus on English retail planning and indicators suggested on public documents. Finally, 
some concluding remarks will be made. Although there is some research on this topic (Hogg et al. 2001, 2004; Pal, Sanders 1997; Centre for Advanced Spatial Analysis 2000, Ravenscroft 2000) there is a need to update it. Even though there is some background of private commissioned reports (see for example CocaStefaniak 2013; BIS 2010, 2011) at some points this analysis has a descriptive nature because there is still a lack of recent scientific discussion on the use of indicators in retail planning, gap that this article tries to overcome and constitutes, at same time, part of the novelty of this article and the reason why this research may be of interest for researchers, urban planners and practitioners.

\section{The process of evaluation}

Evaluation is a very inclusive process used in a wide array of contexts and at different stages: ex-ante, ongoing or ex-post. The ex-ante evaluation means that it will be analysed the projected impacts of the subject of evaluation before it is implemented. The ongoing is done during the implementation of the programme and usually it's used to still make some amendments. Finally, according to Alexander (2006:7), the ex-post evaluation "involves measuring or assessing the impacts and effects of the subject undertaking - policy, plan, program or project."

Among many other contexts, it can be applied in an entrepreneurial environment, aiming the evaluation of customer satisfaction or for the evaluation of tourist's satisfaction regarding a particular touristic destination. It also can be used in the context of development programs, regeneration projects or public policies. In this case, the importance of evaluation arises from the need to inform stakeholders such as agencies or funding institutions, local authorities, planning officers, retailers and taxpayers if the program for which contributed, managed to achieve the desired impact (Greene 2009: 216). More than information about the amount spent is crucial to know the achieved impacts. As a complement, the evaluation process can be useful to support policy decisions to improve the performance of ongoing and future programs (Wholey 2010: 652). While focusing on public sector productivity, Hatry (1978: 28) used a sports analogy that also suits this research: "Unless you are keeping score, it is difficult to know whether you are winning or losing". The evaluation exercise should be an important source of learning and social innovation, especially for those responsible for the instrument under assessment, for institutions and actors with whom they come into interaction in this context, and to the general public (Ferrão, Mourato 2010: 21). Focusing on urban planning, Oliveira and Pinho (2009: 36) con- sider that evaluation improves its practice, legitimate these processes to citizens, help policy planners and decision-making and allows the construction of a practical planning based on continuous learning process. Despite the acknowledged importance, it's usual the existence of gaps in these processes. Dhaliwal and Tulloch (2011: 18) focusing on social policies explains them clearly:

"Billions of dollars are spent every year on development policies and programs, but there is relatively little rigorous evidence on the true impact these programs have on the lives of the poor. [...] This scarcity of rigorous evidence on program impact, and the technical language in which the little evidence that does exist is presented, makes it inaccessible to policymakers, many of whom then rely on intuition and anecdotal evidence in deciding which programs to fund and implement".

\section{Evaluation: frameworks and methods}

The evaluation of policies and/or programmes is usually framed in a conceptual framework and subsequently is realized through different methods. In the European context, the work of the European Commission stands out. In order to evaluate the application of the Structural Funds two studies of higher importance were developed: MEANS (Means for evaluating actions of a structural nature) and the guide EVALSED (The resource for the evaluation of Socio-Economic Development). The first consists of six volumes and was prepared by the European Commission in 1999, aiming to present a coherent set of methods to respond to the problems encountered during the evaluation of interventions supported by the Structural Funds (European Commission 1999: 5). Following improvements in the field of evaluation, new experiences in European policies, the increasing number of EU members and the need for a more strategic approach in the evaluation of Structural Funds, it became necessary to update this publication. In this context, in 2008, the study EVALSED was released, comprising a support guide and three books: Evaluation approaches for particular themes and policy areas; Evaluation methods and techniques; Resource material on evaluation capacity building. This is a general study and assumed the difficulty of bringing together the ideal conditions to carry out an evaluation, either for the lack of data, the limitation of time, the availability of tools or the ability to perform it (European Commission 2008: 5).

The framework developed in this guide is described in the Figure 1. It considered necessary to analyse the objectives, inputs, outputs and results in order to obtain the specific impacts of a certain programme. Depending on the depth of analysis, this guide also 


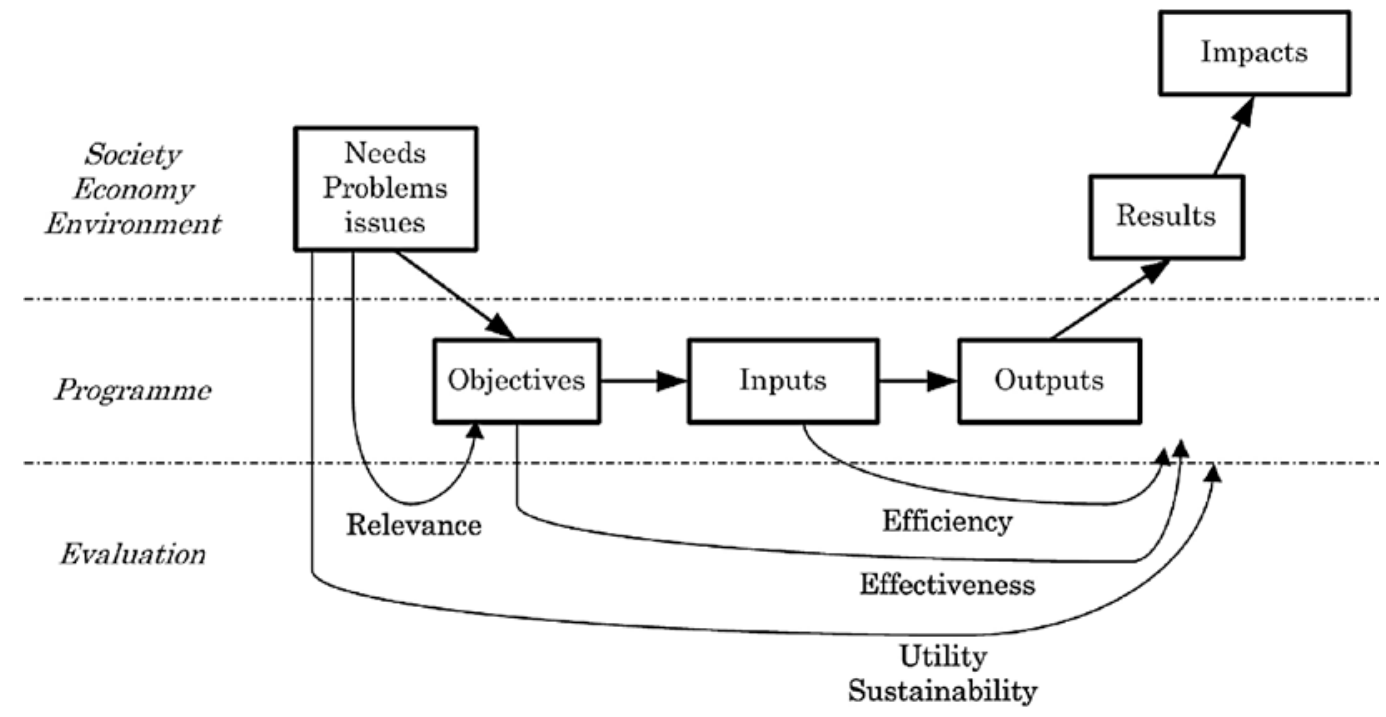

Fig. 1. Selecting priority evaluation questions Source: European Commission (2008).

identifies four evaluation categories that relates to the relevance of the program, with its efficiency, effectiveness and utility (European Commission 2008: 41).

This guide (European Commission 2008: 42) explains what is meant by each of the categories. So, relevance "refers to the appropriateness of the explicit objectives of the programme in relation to the socio-economic problems it is supposed to address"; effectiveness "concerns whether the objectives formulated in the programme are being achieved, what the successes and difficulties have been, and how appropriate the solutions chosen have been and what is the influence of external factors"; "efficiency is assessed by comparing the results obtained or, preferably, the impacts produced, and the resources mobilized" and utility "judges the impacts obtained by the programme in relation to broader societal and economic needs". This study also refers to sustainability, evaluation process that examine the duration of impacts. In this respect it must be examined what realistic expectations one may consider.

Other frameworks have been developed, like the one presented by Moore and Spires (2000: 219, based on the work of PACEC 1999), which presented a conceptual framework focused on the ex-post evaluation of urban regeneration programmes. Although there are some similarities with the Evalsed guide framework, especially regarding the outlined concepts, these are displayed in a more integrated way, which makes it easier to understand. In this framework it's enhanced the strategic objectives of the programmes, inputs, activity measures, synergy, outputs and outcomes measures, gross impacts and the Net impacts on urban areas. Coca-Stefaniak (2013) performance framework is another example and is anchored on four themes: people and footfall; diversity and vitality of place; consumer and business perceptions; economic characteristics. Although specifically developed for town centres this is a framework based on an ongoing evaluation process and, therefore, with limitations as to the depth of the performed analysis.

Underlying the different evaluation frameworks is the use of diverse kind of methods, like Importanceperformance analysis (see Riviezzo et al. 2009; Musa et al. 2010), Analytical Hierarchy Process (PinedaHenson et al. 2002; Saaty, Vargas 2013), Cost-benefit analysis (Nyborg 2014), Multi-criteria analysis (Macharis, Bernardini 2015), among many others.

\section{The use of indicators in English retail planning}

Retail planning in England was, until the mid-1990s, characterized by the reduced restriction to the appearance of new commercial formats and their deployment outside the established traditional centres of commerce. After that period there was an inversion with the rise of Town Centre First policy, whose first approach was in 1993, through Planning Policy Guidance 6 (PPG6). In this period, we also watch the use of retail as a crucial element of several urban regeneration projects, mainly through the deployment of shopping centers in central areas (see Lowe 2005, 2007; Jayne 2006) and the emergence and dissemination of town centre management schemes. Against this background, the English government started to incorporate a set of indicators in the main key documents of retail planning. These indicators, entitled Key Performance Indicators (KPI) (Hogg et al. 2004) have been suggested in several 
pieces of legislation of that country (Planning Policy Guidance (PPG) and Planning Policy Statement (PPS)). The main objective is to measure the health of town centres. It is accepted as relevant the use of indicators to this purpose because it allows the periodic monitoring of the town centre and to correct some aspect in which the centre is not working properly. The use of the term "health" in this context has been widely spread in the literature that uses English case studies and the set of indicators used to measure it is called Town Centre Health Check. Alongside, it also allows the justification of the investment made by developers in two stages. In the first, informs investors about the relevance of the performed intervention. In the second stage, serves to attract new developers, by demonstrating the return of the investment made by the already established investors.

In England, although the collection of indicators is not mandatory but only recommended, it should be done systematically, allowing to trace the regular evolution of the area. The indicators presented in Table 1 began to be suggested in the revision of the document that guided the development of retail, the revised Planning Policy Guidance 6 (PPG6) of 1993. In this document only seven indicators were suggested. In the following year, with URBED report "Vital and Viable Towns Centres: Meeting the Challenge" (URBED 1994), this number remained unchanged although retailer representation was replaced by the State of town centre environmental quality. This report also pointed out the importance of vitality and viability in the analysis of the health of town centre. Other indicators were indicated, but have been regarded as of marginal importance.

After 1994 three other documents were produced, all of them incorporating indicators considered relevant to measure the vitality and viability of town centres. With the suggestion of indicators, through documents with national coverage, it is intended that their collection become standardized, allowing the comparison between different areas.

The 1996 revision of PPG6 extended the number of indicators to eleven. The introduction of new docu-

Table 1. Indicators used in the documents relating to retail planning in England

\begin{tabular}{|c|c|c|c|c|c|c|}
\hline Indicators & $\begin{array}{l}\text { PPG6 } \\
(1993)\end{array}$ & $\begin{array}{l}\text { URBED report } \\
\text { (1994) }\end{array}$ & $\begin{array}{l}\text { PPG6 } \\
(1996)\end{array}$ & $\begin{array}{l}\text { PPS6 } \\
(2005)\end{array}$ & $\begin{array}{l}\text { PPS4 } \\
(2009)\end{array}$ & $\begin{array}{l}\text { NPPF } \\
(2012)\end{array}$ \\
\hline Diversity of uses & $x$ & $x$ & $x$ & $x$ & $x$ & \\
\hline Retailer representation & $X$ & & $X$ & $x$ & $X$ & \\
\hline Retailer demand (plans to change) & $\mathrm{x}$ & $x$ & $x$ & $x$ & $\mathrm{X}$ & \\
\hline Shopping rents & & & $x$ & $x$ & $x$ & \\
\hline Proportion of vacant street level property & $\mathrm{x}$ & $X$ & $X$ & $X$ & $X$ & \\
\hline Commercial yields on non-domestic property & $x$ & $\mathrm{x}$ & $x$ & $x$ & $x$ & \\
\hline Pedestrian flows & $\mathrm{x}$ & $x$ & $x$ & $\mathrm{X}$ & $x$ & \\
\hline Accessibility & & & $X$ & $X$ & $X$ & \\
\hline Customer views and behaviour & & & $x$ & $x$ & $x$ & \\
\hline Perception of safety \& occurrence of crime & & & $x$ & $x$ & $x$ & \\
\hline State of town centre environmental quality & & $x$ & $x$ & $x$ & $x$ & \\
\hline Physical structure of the centre & $\mathrm{x}$ & $x$ & & & & \\
\hline $\begin{array}{l}\text { The amount of retail, leisure and office floor } \\
\text { space in edge-of-centre and out-of-centre } \\
\text { locations; }\end{array}$ & & & & $\mathrm{x}$ & $x$ & \\
\hline $\begin{array}{l}\text { Potential capacity for growth or change of } \\
\text { centres in the network }\end{array}$ & & & & $x$ & $x$ & \\
\hline $\begin{array}{l}\text { Land values and the length of time key sites } \\
\text { have remained undeveloped }\end{array}$ & & & & & $x$ & \\
\hline Other indicators & \multicolumn{6}{|c|}{$\begin{array}{l}\text { Demand from retail multiples; ranking of multiples } \\
\text { presence; space in use; profile of retailers; vacancy } \\
\text { rates; quality of the centre. }\end{array}$} \\
\hline
\end{tabular}

Source: Centre for Advanced Spatial Analysis (2000); URBED (1994); Department of the environment (1996); Office of the Deputy Prime Minister (2005); Communities and local government $(2009,2012)$. 
ments in 2005 and 2009 further broadened this number to thirteen and fourteen, respectively.

The last retail planning document - National Planning Policy Framework (Department for Communities and Local Government 2012) - edited in 2012 is the first, since PPG6 of 1993, to not incorporate any indicators. Only five indicators remained during the 16 years and five key documents: diversity of uses, retailer demand, proportion of vacant street level property, commercial yields on non-domestic property and pedestrian flows. The remaining indicators were only suggested in fewer cases, breaking the continuity that should characterize evaluation.

As new regulations were released, new indicators were incorporated, such as accessibility, customer views and behaviour, perceptions of safety and occurrence of crime, among others. Assuming the difficulty to collect them, it was probably expected that increasing the number of suggested indicators would positively influence the number of those which was going to be effectively collected.

The use of these and/or other indicators is optional. In urban areas, the gathering of indicators has generally been done through Town Centre Health Check, an analogy made to the measurement of the health of town centres. It is available online a wide range of such studies. For example, in the county of Fife, Scotland, several Town Centre Health Check were undertaken, focusing on different aspects: (1) analysis of consumer perceptions of four centres - Glenrothes, Kirkcaldy; St Andrews and Dunfermline. These studies were considered crucial to identify the necessary interventions for maintaining the viability and vitality of those areas (Fife Council 2009, 2011); (2) in 2012 another study was prepared on the perception of the quality of existing core areas, for which visitors and potential investors were interviewed, with the purpose of proceeding to the creation of a marketing strategy oriented to an external audience (Thinkingplace 2012); (3) characterization of the retail sector in this area, serving as support for the various municipal development plans (Roderick MacLean Associates Ltd 2012). In other case, in the health check drawn to the centre of Sutton (London Burough of Sutton 2010), it was decided to collect the indicators suggested in PPS4.

The use of indicators, whether by formal health check lists or other more informal ways can be done by both public and private sector. In the first case, the city council acquires a prominent position. In the second case, the town centre management schemes and, more recently, business improvement districts are increasingly assuming a leading role.

\section{Some constraints in the evaluation process}

Some problems arise from the evaluation approach used in English retail planning. With a focus in urban town centres, one should take in consideration that these areas are very likely to change, making it difficult to correct allocate the responsibility to a certain measure or policy. Another everyday aspects introduces difficulties to the evaluation and data collection mechanisms: (i) sometimes those responsible for the implementation of programmes, policies or projects are more concerned with managing the daily work; (ii) some necessary data for evaluation may not be easy to get. For example, data relating to the viability of the area, such as revenue and the number of unoccupied stores and data relating to vitality, as the pedestrian flow are not available and are very expensive to obtain. The allocation of human resources to the collection of data is, most of the times, hard to achieve, regardless whether it will be collected by public local authorities or private schemes or associations. In addition to these difficulties, in order to understand the evolution of the areas, it is necessary that both the vitality-related data and those relating to the viability would be collected periodically, which usually discourage their gathering and makes it an unfeasible process. Sometimes, as Hogg et al. (2004: 313) attested even if a certain indicator is considered relevant by a project manager, it still may not be used, which will introduce limitations to the comparability of different areas. These problems are not restricted to the English, British or even the European context. Mullin and Kotval (2003: 11) identified these difficulties in the North American context. According to these authors, although most central areas revitalization projects intend to increase the vitality, viability and sustainability of targeted areas, actually end up not establishing any criteria for the evaluation of projects. The evaluation of projects eventually falls back on the intuition of local public authorities.

It has also been a problem in terms of scale and comparability of data. In the English national context, the range of intervened areas by regeneration projects has been very wide. Evaluations, especially those based exclusively on the collection of indicators, can hardly incorporate local specificities of disturbed areas. Apart from these features, the presence of some proactive stakeholders can be a decisive factor in the success of the project. As identified in the literature, the presence of these local leaders (Forsberg et al. 1999; Purdue et al. 2000; Hambleton 2003; Hambleton et al. 2001) can decisively influence the success or failure of a project. 


\section{Conclusions}

While it is visible an effort to carry out evaluation processes in English retail planning, through the suggestion of indicators to allow the analysis of the health of town centres, there is no integrated information enabling an assessment of impacts, at least one that would be approximated to a framework like the ones developed by the European Commission and PACEC. What we found in the key documents is a set of indicators, whose variability between documents doesn't facilitate the comparison or the analysis of the temporal evolution. Although there are some private reports (Coca-Stefaniak 2013; BIS 2011, 2010) they reflect the funding association point of view, which may be different than the one the national government may have.

One may conclude that indicators used in English retail planning documents are unframed and should be in a framework that would justify its use by the different stakeholders, which therefore, could recognize its importance. We conclude that a smaller set of well-established indicators that may persist over time would be the better solution. Therefore, it would allow the temporal comparison of the same area and the territorial comparison between different town centres or intervened areas. Thus, we recommend to look back to previous and current public documents (Table 1) and give priority to the indicators that were suggested in all or the majority of the documents. Hence, regardless of the limitations, that set of indicators would still give an overview of the evolution of a certain town centre, instead of the photographic view that indicators collected only once (temporal dimension) give. Even though it was not the aim pursued in this article, with this research we have somehow path the way and demonstrate the necessity of a research that would establish such a set of indicators. In practical terms, the constraints found in the English context are important to urban planners, practitioners and academics because it may provide some assistance in the definition of future evaluation indicators and conceptual frameworks, not only in England but also in other countries.

\section{Acknowledgements}

This work was supported by the Portuguese national funding agency for science, research and technology. We wish to thank the Center for Geographical Studies from Lisbon University, the editors of this journal and the two anonymous reviewers for their comments on the previous version of the paper.

\section{References}

Alexander, E. 2006. Evolution and status: where is planning-evaluation today and how did it get here? In E. Alexander (Ed.). Evaluation in planning - evolution and prospects. Hampshire: Routledge, 3-15.

Association of town centre management 2015. Town Centre Health Check [online], [cited October 2015]. Available from Internet http://www.towncentrehealthcheck.org.uk/

Barth, K.; Hartmann, M. 2003. Germany, in S. Howe (Ed.). Retailing in the European Union: structures, competition and performance. London: Routledge, 56-80.

BIS. 2011. Understanding High Street Performance [online], [cited 23 October 2015]. Department for Business, Innovation and Skills, UK. Available from Internet: https://www.gov.uk/government/uploads/system/uploads/attachment_data/file/31823/11-1402-understanding-high-street-performance.pdf

BIS. 2010. Healthy High Street? A Healthcheck for High Streets and Town Centres [online], [cited 23 October 2015]. Department for Business, Innovation and Skills, UK. Available from Internet: https://www.atcm.org/townteamuploads/1183-ahealthckechforhightstreetsbis

Centre for Advanced Spatial Analysis. 2000. Town centre vitality \& viability: a review of the health check methodology: pilot study. A report for the national retail planning forum. London.

Coca-Stefaniak, A. 2013. Successful town centres: developing effective strategies. Technical report. Association of Town \& City Management, UK.

Colla, E. 2003. France, in S. Howe (Ed.). Retailing in the European Union: structures, competition and performance. London: Routledge, 23-55.

Communities and Local Government (CLG). 2012. National planning policy framework. Communities and Local Government, UK.

Communities and Local Government (CLG). 2009. PPS 4 planning for sustainable growth. Communities and Local Government, UK.

Department for Communities and Local Government 2012. National Planning Policy Framework. Department for Communities and Local Government, London.

Department of the Environment (DOE). 1996. Revised PPG6. Department of the Environment, UK.

Dhaliwal, I.; Tulloch, C. 2011. Part 4: Using impact evaluations to inform policy, in Evidence for social policy and practice: perspectives on how research and evidence can influence decision making in public services. Nesta, London, 18-23 [online], [cited 05 January 2015]. Available from Internet: http://www.nesta.org.uk/sites/default/files/evidence_for_ social_policy_and_practice.pdf

European Commission. 2008. EVALSED: The resource for the evaluation of socio-economic development. Luxembourg [online], [cited 04 August 2011]. Available from Internet: http://ec.europa.eu/regional_policy/sources/docgener/ guides/cost/guide2008_evalsed.pdf

European Commission. 1999. MEANS collection, evaluating socio-economic programmes. European Commission, Italy.

Evers, D. 2002. The rise (and fall?) of national retail planning, Tijdschrift voor Economische en Sociale Geografie 93(1): 107-113. https://doi.org/10.1111/1467-9663.00186

Ferrão, J.; Mourato, J. 2010. A avaliação de políticas públicas como factor de aprendizagem, inovação institucional e cid- 
adania, Revista Brasileira de Estudos Urbanos e Regionais 12(1): 9-28.

Fife Council. 2011. Town Centre perception study 2009 [online], [cited 20 November 2014]. Fife Council. Available from Internet: http://www.fifedirect.org.uk/publications/index. $\mathrm{cfm}$ ? fuseaction $=$ publication. pop $\&$ pubid $=936 \mathrm{CE} 011-$ 012B-F11C-F2ECCC3F3F706C40

Fife Council 2009. Town Centre perception study 2008 [online], [cited 20 November 2014]. Fife Council. Available from Internet:. http://www.fifedirect.org.uk/publications/index. $\mathrm{cfm} ?$ fuseaction $=$ publication. pop\&pubid $=91 \mathrm{D} 505 \mathrm{EF}-$ F1E9-EAFE-0A9A5BBF4226EFAE

Findlay, A.; Sparks, L. 2014. High Streets and town centres policy, in N. Wrigley, E. Brookes (Eds.). Evolving High Streets: resilience \& reinvention. Economic and Social Research Council (ESRC), 12-15 [online], [cited 24 October 2015]. Available from internet: http://www.riben. org.uk/Cluster_publications_\&_media/Opinion_Pieces_ Southampton_Nov_2014.pdf

Forsberg, H.; Medway, D.; Warnaby, G. 1999. Town Centre Management by co-operation - evidence from Sweden, Cities 16(5): 315-322. https://doi.org/10.1016/S0264-2751(99)00029-3

Greene, F. 2009. Assessing the impact of policy interventions: the influence of evaluation methodology, Environment and Planning C: Government and Policy 27: 216-29. https://doi.org/10.1068/c07103b

Guimarães, P. 2016. Revisiting retail planning policies in countries of restraint of Western Europe, International Journal of Urban Sciences 20(3): 361-380. https://doi.org/10.1080/12265934.2016.1194225

Guy, C. 2007. Planning for retail development, a critical view of the British experience. Oxon: Routledge.

Guy, C. 2002. Is retail planning policy effective? The case of very large store development in the UK, Planning Theory and Practice 3(3): 319-330. https://doi.org/10.1080/1464935022000019554

Hambleton, R. 2003. City leadership and the new public management - a cross national analysis, in Paper to the National Public Management Research Conference, 9-11 October 2003, Washington DC: Georgetown University [online], [cited 05 August 2014]. Available from Internet: http://www.pmranet.org/conferences/georgetownpapers/ Hambleton.pdf

Hambleton, R.; Stewart, M.; Sweeting, D.; Huxham, C.; Vangen, S. 2001. Leadership in urban governance: the mobilisation of collaborative advantage. Full Research Report. Economic and Social Research Council (ESRC), Bristol [online], [cited 05 August 2014]. Available from Internet: https:// s3-eu-west-1.amazonaws.com/esrc-files/outputs/47IUix-vk6njZ8IQYi-iA/oxFKCJsZ1Uqffjc9FcbdAg.pdf

Hatry, H. 1978. The Status of Productivity Measurement in the Public Sector, Public Administration Review 38(1): 28-33. https://doi.org/10.2307/975407

Hogg, S.; Medway, D.; Warnaby, G. 2004. Town centre management schemes in the UK: marketing and performance indicators, International Journal of Nonprofit and Voluntary Sector Marketing 9(4): 309-319. https://doi.org/10.1002/nvsm.256

Hogg, S.; Medway, D.; Warnaby, G. 2001. Towards a typology of marketing town centre management schemes through the use of KPIs. Working Paper WP01/11. Manchester Metropolitan University Business School Working Paper Series, Manchester.
Jayne, M. 2006. Cities and consumption. New York: Routledge. https://doi.org/10.4324/9780203358733

Kärrholm, M. 2012. Retailising space - architecture, retail and the territorialisation of public space. Surrey: Ashgate.

London Burough of Sutton. 2010. Sutton Town centre health check. London [online], [cited 17 November 2014]. Available from Internet: https://www.sutton.gov.uk/download/downloads/id/1601/final_stc_health_check_jan_2010.pdf

Lowe, M. 2007. Rethinking Southampton and town centre futures, International Journal of retail \& Distribution Management 35(8): 639-464. https://doi.org/10.1108/09590550710758621

Lowe, M. 2005 Revitalizing inner city retail?: The impact of the West Quay development on Southampton, International Journal of Retail \& Distribution Management 33(9): 658-668. https://doi.org/10.1108/09590550510611850

Macharis, C.; Bernardini, A. 2015. Reviewing the use of multi-criteria decision analysis for the evaluation of transport projects: time for a multi-actor approach, Transport Policy 37: 177-186. https://doi.org/10.1016/j.tranpol.2014.11.002

Moore, B.; Spires, R. 2000. Monitoring and evaluation, in Roberts, P., Sykes, H. (Eds.). Urban Regeneration - a handbook. United Kingdom: SAGE Publications, 203-227.

Mullin, J.; Kotval, Z. 2003. Measuring the effectiveness of downtown revitalization strategies, in Landscape Architecture \& Regional Planning Faculty Publication Series. Paper 23 [online], [cited 22 December 2014]. Available from Internet: http://scholarworks.umass.edu/larp_faculty_pubs/23/

Musa, R.; Pallister, J.; Robson, M.; Daud, N. 2010. Application of importance-performance analysis (IPA) to formulate customer satisfaction strategies in the direct sales industry in Malaysia, Business Strategy Series 11(5): 277-285. https://doi.org/10.1108/17515631011080687

Nyborg, K. 2014. Project evaluation with democratic decision-making: what does cost-benefit analysis really measure?, Ecological Economics 106: 124-131. https://doi.org/10.1016/j.ecolecon.2014.07.009

Office of the Deputy Prime Minister (ODPM). 2005. Planning Policy Statement 6: Planning for Town Centres (PPS6). UK [online], [cited 26 November 2014]. Available from Internet: http://webarchive.nationalarchives.gov.uk/20120919132719/ www.communities.gov.uk/publications/planningandbuilding/planningpolicystatement11

Oliveira, V.; Pinho, P. 2009. Evaluating plans, processes and results, Planning Theory \& Practice 10 (1): 35-63. https://doi.org/10.1080/14649350802661741

Pal, J.; Sanders, E. 1997. Measuring the effectiveness of town centre management schemes, International Journal of Retail \& Distribution Management 25(2): 70-77. https://doi.org/10.1108/09590559710160364

Pineda-Henson, R.; Culaba, A. and Mendoza, G. 2002. Evaluating environmental performance of pulp and paper manufacturing using the analytic hierarchy process and life-cycle assessment, Journal of Industrial Ecology 6(1): 15-28. https://doi.org/10.1162/108819802320971614

Purdue, D.; Razzaque, K.; Hambleton, R.; Stewart, M. 2000. Community leadership in area regeneration. Bristol: The Policy Press [online], [cited 05 August 2014]. Available from Internet: https://www.jrf.org.uk/file/36412/download ?token = vd_DegPU

Ravenscroft, N. 2000. The vitality and viability of town centres, Urban Studies 37(13): 2533-2549. https://doi.org/10.1080/00420980020080681 
Riviezzo, A.; Nisco, A.; Napolitano, M. 2009. Importanceperformance analysis as a tool in evaluating town centre management effectiveness, International Journal of Retail \& Distribution Management 37(9): 748-764. https://doi.org/10.1108/09590550910975808

Roderick Maclean Associates Ltd. 2012. FIFE retail capacity study. Fife [online], [cited 18 August 2014]. Available from Internet:

http://www.fifedirect.org.uk/publications/index.cfm?fuseaction $=$ publication.pop\&pubid $=\mathrm{A} 5 \mathrm{~B} 1650 \mathrm{~F}-\mathrm{C} 81 \mathrm{~F}-$ 3203-039BCB59B898C799

Saaty, T.; Vargas, L. 2013. Decision making with the analytic network process - economic, political, social and technological applications with benefits, opportunities, costs and risks. $2^{\text {nd }}$ ed. New York: Springer. https://doi.org/10.1007/978-1-4614-7279-7

Schiller, R. 1994. Vitality and viability: challenge to the town centre, International Journal of Retail \& Distribution Management 22(6): 46-50. https://doi.org/10.1108/09590559410070321

Spierings, B. 2006. Window on the Netherlands - the return of regulation in the shopping landscape? Reflecting on the persistent power of city centre preservation within shifting retail planning ideologies, Tijdschrift voor Economische en Sociale Geografie 97(5): 602-609. https://doi.org/10.1111/j.1467-9663.2006.00366.x

Thinkingplace 2012. Fife Perception Study - Final Report. Fife [online], [cited 15 April 2013]. Available from Internet: http://www.welcometofife.com

URBED. 1994. Vital and viable towns centres: meeting the challenge. London: DOE.

Wholey, J. 2010. Use of evaluation in government: the politics of evaluation, in J. Wholey, H. Hatry, K. Newcomer (Eds). Handbook of Practical Program Evaluation. $3^{\text {rd }}$ ed. San Francisco, 651-667.

\section{PEDRO PORFÍRIO COUTINHO GUIMARÃES}

PhD. Effective Reseacher in the Center for Geographical Studies, Institute of Geography and Spatial Planning, Lisbon University. His field of research revolve around urban studies, with a specialization in the European retail planning policies. 